\title{
Estimate of Revenues from the Value Added Tax in the Republic of Croatia
}

Kuliš, Danijela; Miljenović, Žarko

Source / Izvornik: Occasional Paper Series, 1997, 1, 1 - 24

Journal article, Published version

Rad u časopisu, Objavljena verzija rada (izdavačev PDF)

https://doi.org/10.3326/ops.2

Permanent link / Trajna poveznica: https:/urn.nsk.hr/urn:nbn:hr:242:398948

Rights / Prava: Attribution-NonCommercial-NoDerivatives 4.0 International/ImenovanjeNekomercijalno-Bez prerada 4.0 međunarodna

Download date / Datum preuzimanja: 2023-04-26

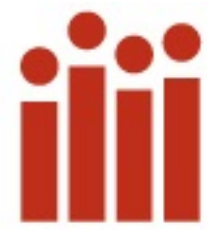

Repository / Repozitorij:

Institute of Public Finance Repository

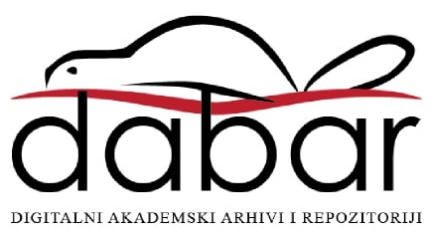




\section{ESTIMATE OF REVENUES FROM THE VALUE ADDED TAX IN THE REPUBLIC OF CROATIA}

Danijela Kuliš \& Žarko Miljenović

Occasional Paper No. 2

October 1997

\footnotetext{
Institute of Public Finance

Katančićeva 5, 10000 Zagreb

CROATIA

tel: +38514591227

fax: +38514819365

ured@ijf.hr

(CInstitute of Public Finance 1997
} 


\title{
ESTIMATE OF REVENUES FROM THE VALUE ADDED TAX IN THE REPUBLIC OF CROATIA
}

\author{
Danijela Kuliš \& Žarko Miljenović
}

This Occasional Paper is part of a research project undertaken by the Institute of Public Finance and financed by the Ministry of Finance of the Republic of Croatia. The research project and the presented paper are published in Croatian in the Institute's journal "Financijska praksa", Volume 20, Number 2 (August 1996). Part I of the paper is written by Danijela Kuliš (Institute of Public Finance, Zagreb), and Part II is written by Žarko Miljenović (then, State Bureau for Macroeconomic Analyses and Forecasts, Zagreb; and now Zagrebačka banka, Zagreb). The project's lead researcher was Dr. Katarina Ott (Institute of Public Finance, Zagreb). 


\title{
ESTIMATE OF REVENUES FROM THE VALUE ADDED TAX \\ IN THE REPUBLIC OF CROATIA
}

\author{
Danijela Kuliš \& Žarko Miljenović
}

ABSTRACT

Croatia is to introduce the value added tax on January 1, 1998. The purpose of this research project was to make an estimate of VAT revenues. The estimates were made using two methods: first, according to other similar estimates, and second, through macroeconomic aggregates. Using the first method, and making a comparison with countries which have a single rate similar to that of Croatia (Denmark 22\% and Norway $20 \%$ ) and a similar base to that of Croatia (all goods and services), the author foresees that after the introduction of VAT the revenues would represent about $10 \%$ of GDP. Using the second method the author concludes that the revenues collected from VAT would make about $12 \%$ of GDP. So according to both methods a reduction of revenues from indirect taxation is expected in Croatia after the introduction of VAT: In recent years sales tax has been making about $13 \%$ of GDP. 


\section{ESTIMATE OF REVENUES FROM THE VALUE ADDED TAX \\ IN THE REPUBLIC OF CROATIA}

\section{ESTIMATE OF REVENUES FROM THE VALUE ADDED TAX IN CROATIA ACCORDING TO OTHER SIMILAR ESTIMATES}

When the tax system is undergoing change, one of the most important questions facing economic policy makers is how that change will affect tax revenues as a fundamental determinant of fiscal policy. Replacing the sales tax with the VAT in Croatia is a fundamental change which will have a significant impact.

\section{Sales Taxes on Goods and Services in Croatia}

Along with the income tax, the sales tax on goods and services is one of the largest generators of tax revenues of countries with modern tax systems.

The share of the sales tax and excise taxes in 1995 (Table 2) was 60\% of Croatia's total tax revenues. The share in GDP (gross domestic product) was been $18.8 \%$, which is 6.5 percentage points higher than the average share in the European countries of the OECD.

In the OECD countries sales taxes on goods and services in 1992 represented an average $11.2 \%$ share in GDP and comprised almost one-third of all tax revenues.

Sales of goods and services are taxed in Croatia under the Law on the Sales Tax on Goods and Services, which was adopted on July 24, 1991 (Narodne novine [Official Gazette of the Republic of Croatia], No. 36/1991). The Law on sales tax has been frequently changed since that time.

The amendments to statutes on taxation of goods and services and the establishment of new excise taxes in July 1994 were meant to improve the Croatian tax system and also bring it closer to the tax systems in countries with advanced market economies.

From 1993 to 1994 the rates of the sales tax were reduced. The number of rates was reduced, and that already signified certain preparations being made for adoption of the value added tax. The 
principal feature of the present Croatian sales tax on goods and services is that taxation occurs in wholesale trade and then mostly in retail trade. The rates of the sales tax are proportional and are fixed in a percentage of the sales price.

All goods are also subject to the sales tax on services in all phases of production, and the sales tax on services is also added to the final retail price, which contains the sales tax on goods. The sales tax on services is paid even on goods exempt from payment of the sales tax on goods, excepting: petroleum products, electric power, tobacco products, drugs, orthopedic devices and aids, organic and chemical fertilizers, commemorative minted coins, numismatic specimens, and collections of minted coins and gold money; bread, milk, lard, oil, and sugar; natural gas; city or mixed gas for general consumption derived from LP gas.

The shortcomings of the present tax system are manifested in its cumulative effect, since the more phases there are in the production process, the higher the tax burden on the product is. The large number of deductions and exemptions also complicates administration as well as the monitoring of tax collection. The large number of different tax rates results in unequal tax burdens and therefore unequal business conditions. The opportunity to make a declaration that a product is used for resale, production, equipment, and the like, and so is not subject to the sales tax, encourages tax evasion. End products which are exported are exempt from payment of the sales tax on products, but they are subject to the sales tax on services performed on the export goods by other entrepreneurs. 
Table 1. Sales Tax on Goods and Services and Excise Taxes in Croatia

\begin{tabular}{|c|c|c|c|c|c|c|}
\hline & \multicolumn{6}{|c|}{$\begin{array}{l}\text { - HRK } \\
\text { - current prices }\end{array}$} \\
\hline & \multicolumn{3}{|c|}{1994} & \multicolumn{3}{|c|}{1995} \\
\hline & sales tax & excise taxes & total & sales tax & excise taxes & total \\
\hline \begin{tabular}{|l} 
January \\
\end{tabular} & $1,023,816,099$ & & $1,023,816,099$ & $959,424,781$ & $376,682,934$ & $1,336,107,715$ \\
\hline February & $975,936,791$ & & $975,936,791$ & $1,041,565,471$ & $350,861,375$ & $1,392,426,846$ \\
\hline March & $1,047,084,883$ & & $1,047,084,883$ & $1,057,997,616$ & $343,558,364$ & $1,401,555,980$ \\
\hline April & $1,220,666,039$ & & $1,220,666,039$ & $926,685,456$ & $373,887,845$ & $1,300,573,301$ \\
\hline May & $1,027,754,466$ & & $1,027,754,466$ & $968,026,120$ & $349,586,590$ & $1,317,612,710$ \\
\hline June & $1,243,609,161$ & & $1,243,609,161$ & $1,167,432,748$ & $457,773,428$ & $1,625,206,176$ \\
\hline July & $1,217,002,908$ & $179,368,636$ & $1,396,371,544$ & $1,092,843,185$ & $433,882,215$ & $1,526,725,400$ \\
\hline August & $1,076,959,215$ & $476,233,369$ & $1,553,192,584$ & $1,042,227,792$ & $447,800,212$ & $1,490,028,004$ \\
\hline September & $1,162,875,835$ & $477,119,293$ & $1,639,995,128$ & $1,189,742,159$ & $487,401,492$ & $1,677,143,651$ \\
\hline October & $1,007,697,808$ & $371,941,078$ & $1,379,638,886$ & $1,086,854,796$ & $468,021,177$ & $1,554,875,973$ \\
\hline November & $971,470,339$ & $398,099,137$ & $1,369,569,476$ & $1,047,649,313$ & $439,266,142$ & $1,486,915,455$ \\
\hline December & $1,168,117,925$ & $401,011,969$ & $1,569,129,894$ & $1,220,887,570$ & $431,717,779$ & $1,652,605,349$ \\
\hline TOTAL & $13,142,991,469$ & $2,303,773,482$ & $15,446,764,951$ & $12,801,337,007$ & $4,960,439,553$ & $17,761,776,560$ \\
\hline
\end{tabular}

Source: Report on Own Revenues of the State, County [županija], District [kotar], and Municipality [općina] Budgets, P-2, Payments Bureau, Central Office, Zagreb 
Table 2. Tax Revenues and Customs Duties in Croatia

-millions HRK

-current prices

\begin{tabular}{|c|c|c|}
\hline & 1994 & 1995 \\
\hline TOTAL TAX REVENUES & 25,579 & 29,594 \\
\hline sales tax on goods and services & 13,142 & 12,801 \\
\hline excise taxes & 2,304 & 4,960 \\
\hline income tax & 5,366 & 5,854 \\
\hline profit tax & 763 & 1,362 \\
\hline gambling tax & 59 & 86 \\
\hline county taxes & 70 & 77 \\
\hline municipal taxes & 414 & 172 \\
\hline personal income tax & 5 & 2 \\
\hline other & & 2 \\
\hline sales tax on real estate & & 355 \\
\hline TOTAL DUTIES AND CUSTOMS CHARGES & 3,456 & 3,923 \\
\hline duties & 677 & 783 \\
\hline customs charges & 2,075 & 3,138 \\
\hline other customs charges & 703 & 2 \\
\hline GROSS DOMESTIC PRODUCT & 85,299 & 94,564 \\
\hline SALES TAX ON GOODS AND SERVICES & 13,142 & 12,801 \\
\hline SHARE IN GDP (in \%) & 15.41 & 13.54 \\
\hline EXCISE TAXES & 2,304 & 4,960 \\
\hline SHARE IN GDP (in \%) & 2.70 & 5.25 \\
\hline TOTAL (EXCISE AND SALES TAXES) & 15,446 & 17,761 \\
\hline SHARE IN GDP (in \%) & 18.11 & 18.78 \\
\hline TOTAL TAX REVENUES & 25,579 & 29,594 \\
\hline $\begin{array}{l}\text { SHARE OF THE SALES TAX AND EXCISE TAXES IN } \\
\text { TOTAL TAX REVENUES (in \%) }\end{array}$ & 60.39 & 60.02 \\
\hline
\end{tabular}

Source:

Report on Own Revenues of the State, County [županija], District [kotar], and Municipality [općina] Budgets, P-2,

Payments Bureau, Central Office, Zagreb

Gross domestic product: Estimate of the State Bureau for Macroeconomic Analyses and Forecasts 


\section{Estimate of Future Revenues from the Value Added Tax in Croatia according to other similar estimates}

Introduction of the value added tax (VAT) brings about significant changes in the tax system, and the question raised most often is how these changes will affect the realization of future budget revenues. The main determinants of revenues will be the level of the tax rate, the number of rates applied, and the breadth of the tax base, which is determined by the size and number of exemptions. In estimating future revenues, we should also be mindful of the higher operating costs of the tax administration, taking into account preparation of the tax administration and taxpayers at the outset when the new tax is being put into practice.

We will attempt here to indicate the main determinants affecting realization of revenues from the VAT (Bogetić \& Hassan, 1993), so that on the basis of the model used it will be possible to forecast future revenues from the VAT in Croatia.

Numerous studies have indicated that one rate (between 10 and 20\%) with few exemptions and with broad base is more favorable than application of several rates and more exemptions, which reduce the tax base and complicate tax collection.

Since only one rate of the VAT is foreseen in Croatia at a level of $22 \%$, a comparison with countries which have a single rate could forecast future revenues expressed as a share in the GDP.

The analysis of the impact of the level of the tax rate and the breadth of the tax base on realization of revenues covers 49 countries (Table 3 ).

The average is $14.4 \%$, and it realizes a share of $5.1 \%$ of the GDP, implying the average revenue productivity ratio of $35 \%$ of GDP. This means that raising the tax rate one percentage point would on the average increase the share of revenues in GDP by $0.35 \%$. The average rate of revenue productivity in countries with several rates is $0.35 \%$, somewhat lower than for countries which have a single rate $(0.37 \%)$. It follows that using several rates would not generate larger revenues than applying one rate.

What is more, a larger number of rates augments administrative problems and costs of collecting the value added tax (Tait, 1988). 
Revenues from the VAT and revenue productivity vary from country to country. The lowest revenue productivity rate was in Guinea $(0.044 \%)$, where the rate of the value added tax is $13.5 \%$. The highest revenue productivity rate was in Israel $(0.653 \%)$, where a single $15 \%$ rate of the VAT is applied. The difference derives from a more competent and effective tax administration and a broader tax base in Israel.

There is positive correlation between tax rates and tax revenues (Gillis, Shoup \& Sicat, 1990), while the rate spread, defined as the absolute difference between the highest and lowest rates, can have a negative impact on realization of revenues. A high number of exemptions has a significant impact on the breadth of the tax base (Kay \& Davis,1987).

Exemption of all services from the tax base considerably reduces revenues and at the same time necessitates a higher rate on the goods that are taxed in order to bring in the necessary revenues.

According to Cnossen (1991), there are four types of tax base, encompassing the following:

1. all goods and services $(\mathrm{G}+\mathrm{S})$,

2. goods and selected services $(\mathrm{G}+\mathrm{ST})$,

3. only goods $(\mathrm{G})$,

4. consumer goods and capital goods $(\mathrm{C}+\mathrm{CG})$, or consumer goods, selected services and capital goods $(\mathrm{C}+\mathrm{ST}+\mathrm{CG})$.

$$
(\mathrm{G}=\text { goods } ; \mathrm{S}=\text { services; } \mathrm{ST}=\text { selected services } ; \mathrm{CG}=\text { capital goods })
$$

Two-thirds of the countries have a broad base (all goods and services $\mathrm{G}+\mathrm{S}$ ), and this is the one used most frequently. The breadth of the tax base from country to country differs mostly in the coverage of services. Exemption of services from the tax base could have a negative impact on realization of revenues.

The regression method will be used in an attempt to show which are the main factors determining the level of revenues from the VAT (Bogetic \& Hassan, 1993). The general model will indicate that a growth of revenues from the VAT occurs when the rate is raised and the coverage of the tax base is broadened, while differentiation of the rates causes a rise of costs and thereby a negative impact on revenue: 
where the variables are:

$R E V E N U E=$ a revenue variable defined as the revenue from the VAT expressed as a percentage of the country's GDP rate $=$ rate of the VAT in percentage base $=$ the base is 1 if it includes all goods and services $(\mathrm{G}+\mathrm{S})$; otherwise the base is 0 . range $=$ a measure of rate dispersion

The regression included 34 countries, 20 of them with a single rate and 14 with more than one rate. The linear version of the general model is estimated using the Ordinary Least Squares (OLS) technique. The models of the estimate are shown in Table 4.

Revenues from the VAT depend most of all on the rate of the tax, whose significance is less than $1 \%$ and has an expected positive sign in all variants of the estimate, as well as on the determination coefficient, which is 0.75 for countries with a single rate and 0.57 for countries with more than one rate.

In the 20 countries analyzed which had a single tax rate average revenues realized had a share of $4.7 \%$ in GDP while the average tax rate was $11.3 \%$. Every percentage point of the tax yields $0.50 \%$ in revenues. The estimated rate which will realize positive revenues is close to 2 percent, which can be seen as the minimum rate for future revenues. The coefficient of the rate in the linear model has $71 \%$ significance for realization of revenues.

The estimate can be used for countries preparing to introduce the VAT to support the proposal of using a single rate. For example, a single rate of $18 \%$ was envisaged in Bulgaria when the VAT was introduced.

At that rate, using this model (see Chart 1.), we can conclude that the VAT could realize revenues amounting to about $8.1 \%$ of GDP. However, actual realization of the forecast revenues will also depend on certain other characteristics of the VAT. Two things should be borne in mind. First, the estimate is very approximate and assumes that the other important features of the VAT in Bulgaria (for example, the size of the tax base or the number of exemptions) is similar or very close to the countries shown. When say, the VAT is proposed with a sizable number of exemptions (narrow base), the assumed ratio of the base in this model could exaggerate the future 
revenues; that is, the real or anticipated revenues could be less than those planned and expected. The other fact which makes the estimate a rough approximation is the level of the cost of collecting the tax, which may differ from those assumed in this model. This could also result in collection of smaller revenues than those forecast. Nevertheless, the model provides a rough estimate of distribution around a magnitude which represents future realization of revenues. Estimating the actual 'tax gap,' that is, the ratio between potential and realizable revenues at about $65-75 \%$, those countries could expect an increase in the share of the VAT in GDP between 5 and $6 \%$ when the tax is fully implemented.

Using this model and making a comparison with countries which have a single rate similar to that of Croatia (Denmark 22\% and Norway 20\%) and a similar base to that of Croatia (all goods and services), we can foresee that introduction of the VAT could realize revenues representing about $10 \%$ of GDP. 
Table 3. Value Added Tax Rate, Revenue and Base, Worldwide (1988)

\begin{tabular}{|c|c|c|c|c|}
\hline Country & $\begin{array}{l}\text { VAT revenue as \% } \\
\text { of GDP }\end{array}$ & $\begin{array}{l}\text { Standard } \\
\text { VAT rate }\end{array}$ & $\begin{array}{l}\text { Tax } \\
\text { base }\end{array}$ & Other VAT rates \\
\hline Argentina & 0.8 & 16.0 & $\mathrm{G}+\mathrm{ST}$ & 25 \\
\hline Austria & 6.1 & 20.0 & $G+S$ & 10,32 \\
\hline Belgium & 7.2 & 19.0 & $G+S$ & $1,6,17,25,33$ \\
\hline Bolivia & 2.6 & 10.0 & $\mathrm{G}+\mathrm{S}$ & single rate \\
\hline Brazil & n.a. & 17.0 & $\mathrm{G}+\mathrm{CG}$ & single rate \\
\hline Chile & 8.8 & 16.0 & $\mathrm{G}+\mathrm{S}$ & single rate \\
\hline Colombia & n.a. & 10.0 & $\mathrm{G}+\mathrm{ST}$ & $4,6,15,20,35$ \\
\hline Costa Rica & 3.8 & 10.0 & $\mathrm{G}+\mathrm{ST}$ & single rate \\
\hline Ivory Coast & n.a. & 25.0 & $\mathrm{G}+\mathrm{SG}$ & $11.1,35.1$ \\
\hline Denmark & 9.5 & 22.0 & $\mathrm{G}+\mathrm{S}$ & single rate \\
\hline Dominican Republic & 1.6 & 6.0 & $\mathrm{G}+\mathrm{ST}+\mathrm{CG}$ & single rate \\
\hline Ecuador & 2.5 & 10.0 & $\mathrm{G}+\mathrm{ST}$ & single rate \\
\hline Finland & 8.4 & 19.1 & $\mathrm{G}+\mathrm{ST}+\mathrm{CG}$ & single rate \\
\hline France & 11.9 & 18.6 & $\mathrm{G}+\mathrm{S}$ & $2.1,4,5.5,22$ \\
\hline Germany & 3.8 & 14.0 & $\mathrm{G}+\mathrm{S}$ & 7 \\
\hline Greece & 8.9 & 18.0 & $\mathrm{G}+\mathrm{S}$ & $3,8,36$ \\
\hline Granada & 4.5 & 6.0 & $\mathrm{G}+\mathrm{S}$ & single rate \\
\hline Guatemala & 2.4 & 7.0 & $\mathrm{G}+\mathrm{S}$ & single rate \\
\hline Guinea & 0.6 & 13.6 & n.a. & single rate \\
\hline Haiti & 1.8 & 10.0 & $\mathrm{G}+\mathrm{S}+\mathrm{CG}$ & single rate \\
\hline Honduras & n.a. & 7.0 & $\mathrm{G}+\mathrm{ST}$ & 6 \\
\hline Hungary & 9.1 & 25.0 & $\mathrm{G}+\mathrm{S}$ & 15 \\
\hline Indonesia & 4.5 & 10.0 & $\mathrm{G}+\mathrm{ST}$ & single rate \\
\hline Ireland & 8.5 . & 21.0 & $G+S$ & $2.2,3.3,12.5$ \\
\hline Israel & 9.8 & 15.0 & $G+S$ & single rate \\
\hline Italy & 5.8 & 19.0 & $\mathrm{G}+\mathrm{S}$ & 38 \\
\hline Korea & 3.3 & 10.0 & $\mathrm{G}+\mathrm{S}$ & single rate \\
\hline Luxembourg & 6.8 & 12.0 & $\mathrm{G}+\mathrm{S}$ & 3,6 \\
\hline Madagascar & 1.5 & 15.0 & $\mathrm{G}+\mathrm{S}$ & single rate \\
\hline Mauritius & 2.1 & 5.0 & $\mathrm{G}$ & single rate \\
\hline Mexico & 3.4 & 15.0 & $G+S$ & 6,20 \\
\hline Morocco & n.a. & 9.0 & $\mathrm{G}+\mathrm{S}$ & $7,12,14,19,30$ \\
\hline Netherlands & 8.0 & 18.5 & $G+S$ & 6 \\
\hline New Zealand & 6.7 & 12.5 & $\mathrm{G}+\mathrm{S}$ & single rate \\
\hline Nicaragua & 2.3 & 10.0 & $\mathrm{G}+\mathrm{ST}$ & 6,25 \\
\hline Niger & n.a. & 25.0 & $\mathrm{G}+\mathrm{S}$ & 15,35 \\
\hline Norway & 9.4 & 20.0 & $\mathrm{G}+\mathrm{ST}$ & single rate \\
\hline Panama & 1.1 & 5.0 & $\mathrm{G}+\mathrm{S}$ & single rate \\
\hline Peru & 2.0 & 13.0 & $\mathrm{G}+\mathrm{ST}$ & single rate \\
\hline Philippines & n.a & 10.0 & $G+S$ & single rate \\
\hline Portugal & 6.6 & 17.0 & $\mathrm{G}+\mathrm{S}$ & 8,30 \\
\hline Spain & 4.6 & 12.0 & $G+S$ & 6,33 \\
\hline Sweden & 7.5 & 25.0 & $\mathrm{G}+\mathrm{S}$ & single rate \\
\hline Taiwan & 2.6 & 5.0 & $\mathrm{G}+\mathrm{S}$ & single rate \\
\hline Togo & n.a. & 14.0 & $\mathrm{G}+\mathrm{S}$ & 3 \\
\hline Tunisia & 2.8 & 17.0 & $\mathrm{G}+\mathrm{S}$ & 6,29 \\
\hline Turkey & 1.7 & 12.0 & $\mathrm{G}+\mathrm{S}$ & $1,6,8,20$ \\
\hline Great Britain & 6.0 & 15.0 & $\mathrm{G}+\mathrm{S}$ & single rate \\
\hline Uruguay & 7.0 & 22.0 & $G+S$ & 12 \\
\hline Average & 5.1 & 14.4 & & \\
\hline
\end{tabular}


Table 4. Determinants of VAT Revenues: Regression Results

\begin{tabular}{|c|c|c|c|c|}
\hline $\begin{array}{c}\text { Dependent variable: } \\
\text { VAT revenue to GDP } \\
(\%)\end{array}$ & $\begin{array}{c}\text { (1) } \\
\text { All countries }\end{array}$ & Single rate countries & $\begin{array}{l}\text { (3) } \\
\text { Multiple rate } \\
\text { countries }\end{array}$ & $\begin{array}{c}(4) \\
\text { Differences } \\
(2-3)\end{array}$ \\
\hline Constant & $\begin{array}{c}-0.880 \\
(-0.953)\end{array}$ & $\begin{array}{c}-1.746 \\
(-1.907)\end{array}$ & $\begin{array}{l}-4.805 \\
(-1.909)\end{array}$ & $\begin{array}{c}3.059 \\
(1.168)\end{array}$ \\
\hline Rate & $\begin{array}{c}0.389 \\
(6.293)\end{array}$ & $\begin{array}{c}0.503 \\
(7.519)\end{array}$ & $\begin{array}{c}0.339 \\
(3.025)\end{array}$ & $\begin{array}{c}0.164 \\
(1.276)\end{array}$ \\
\hline Base & $\begin{array}{c}1.426 \\
(1.930)\end{array}$ & $\begin{array}{c}1.313 \\
(1.937)\end{array}$ & $\begin{array}{c}4.490 \\
(2.641)\end{array}$ & $\begin{array}{c}-3.177 \\
(-1.774)\end{array}$ \\
\hline Range & $\begin{array}{l}-0.071 \\
(-1.863)\end{array}$ & - & $\begin{array}{c}0.021 \\
(0.383)\end{array}$ & $\begin{array}{c}-0.021 \\
(-0.394)\end{array}$ \\
\hline $\mathrm{R}^{2}$ & 0.61 & 0.77 & 0.66 & \\
\hline $\mathrm{R}^{2}$ (adjusted) & 0.57 & 0.75 & 0.55 & \\
\hline $\mathrm{F}$ & 15.58 & 29.83 & 6.35 & \\
\hline Number of countries & 34 & 20 & 14 & \\
\hline
\end{tabular}

Source: Bogetić \& Hassan (1993.) 


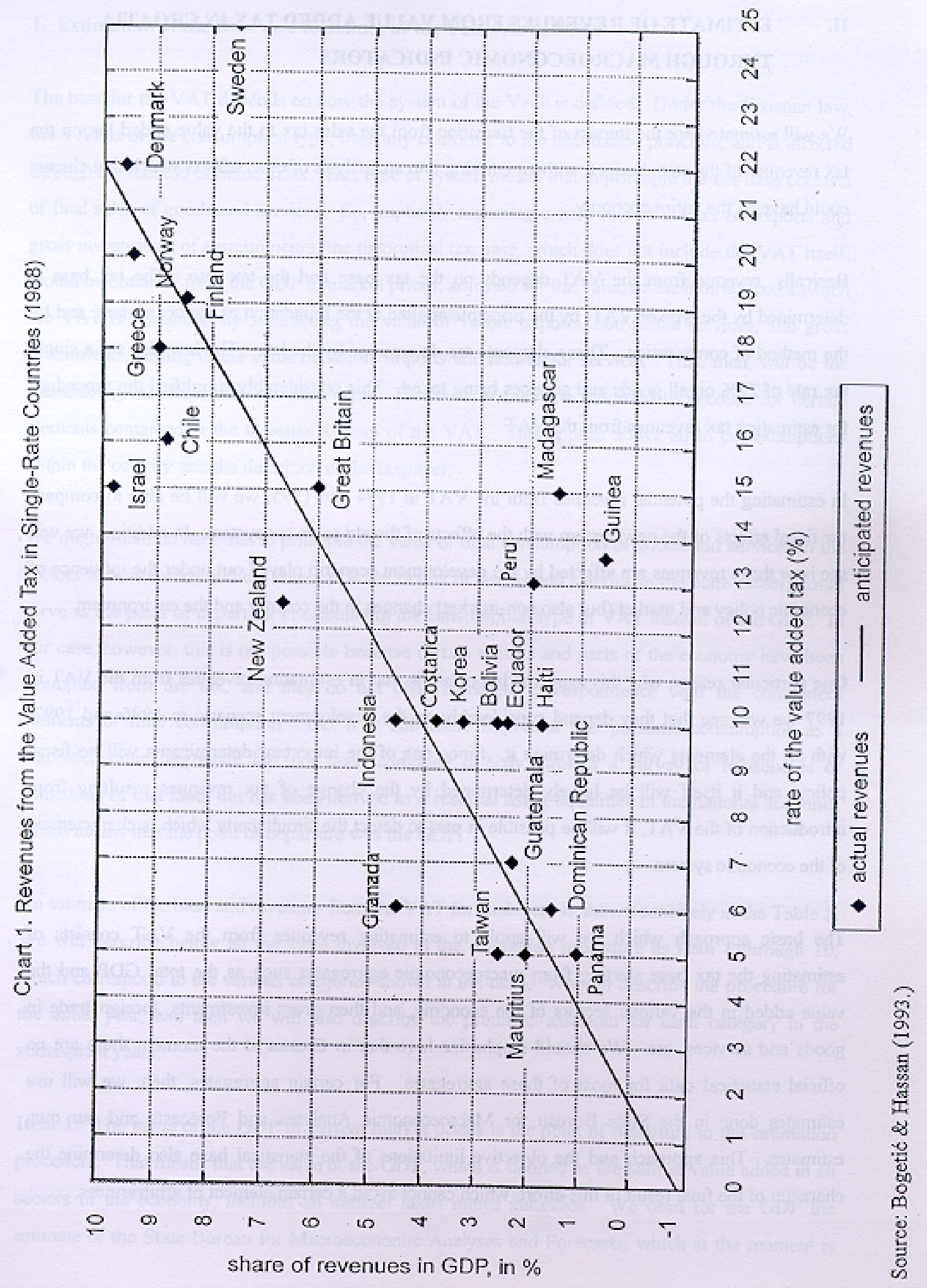




\section{ESTIMATE OF REVENUES FROM VALUE ADDED TAX IN CROATIA THROUGH MACROECONOMIC INDICATORS}

We will estimate here the impact of the transition from the sales tax to the value added tax on the tax revenues of the state budget, without entering into an analysis of other effects which that change could have on the entire economy.

Basically, revenue from the VAT depends on the tax base and the tax rate. The tax base is determined by the type of VAT, by the principle applied at the foundation of the tax system, and by the method of computation. These elements are determined by the law. The law also set a single tax rate of $22 \%$ on all goods and services being taxed. This considerably simplified the procedure for estimating tax revenues from the VAT.

In estimating the potential revenues from the VAT in 1994 and 1995, we will be able to compare the fiscal effects of the new system with the effects of the old sales tax system. In addition, we will see how those revenues are affected by the development scenario played out under the influence of economic policy and market (but also non-market) changes in the country and the environment.

One particular reason why this aspect is important is that in estimating revenues from the VAT in 1997 we will see that they depend considerably on the development scenario in 1996 and 1997 , with all the elements which determine it. Since one of the important determinants will be fiscal policy, and it itself will be largely determined by the change of tax revenues resulting from introduction of the VAT, it will be possible in part to detect the simultaneity which is characteristic of the economic system.

The basic approach which we will apply to estimating revenues from the VAT consists of estimating the tax base starting from macroeconomic aggregates such as the total GDP and the value added in the various sectors of the economy, and then gross investments, foreign trade in goods and services, etc. We should emphasize here that in Croatia at the moment there are no official statistical data for most of these aggregates. For certain aggregates, then, we will use estimates done in the State Bureau for Macroeconomic Analyses and Forecasts and our own estimates. This approach and the objective limitations of the statistical base also determine the character of the final result of this effort, which cannot avoid a certain element of arbitrariness. 


\section{Estimation of the Base and Revenues of the Value Added Tax}

The base for the VAT depends on how the system of the VAT is defined. Under the Croatian law, the VAT is of the consumption type, basically conforms to the destination principle, and is effected through the method of billed sales. This type of system means that in principle the tax base consists of final sales of goods and services. So, implicitly assuming a zero rate of the tax on exports and gross investments of entrepreneurs, the theoretical tax base, which does not include the VAT itself, would be obtained from the GDP in market prices, adjusted for the value of the indirect taxes which the VAT is replacing, by subtracting the value of visible exports, non-factor services, and gross investments, adding in the value of visible imports and non-factor services. This, then, will be the methodological framework we start with. However, it must be modified to account for certain elements contained in the Croatian system of the VAT. This applies above all to tax exemptions within the country and the definition of the taxpayer.

We might mention here that in principle the value of final consumption of goods and services in the sectors of households and the state (after deduction of wages and salaries in the state sector) could serve as the point of departure in calculating the consumption type of VAT instead of the GDP. In our case, however, this is not possible because certain sectors and parts of the economy have been exempted from the tax, and they do not offer complete correspondence with the component elements of final consumption. But it is still more important that personal consumption as a macroeconomic aggregate has not been compiled directly through a survey of households or something of that kind, but has been derived as a residual using equalities in the national accounts, which means that the point of departure was the GDP.

An estimate of the base and revenues from the VAT for each year is shown concisely in the Table 5. We will describe below all the steps involved in the estimation procedure as Item 1 through 10, which correspond to the various categories shown in the table. We will describe the procedure for the initial year, and then we will also describe the premises assumed for each category in the subsequent years.

Item 1: The value of the GDP in current market prices is the point of departure in the estimation procedure. That means that the value of the GDP, which is defined as the sum of value added in all sectors of the economy, includes all indirect taxes minus subsidies. We used for the GDP the estimate of the State Bureau for Macroeconomic Analyses and Forecasts, which at the moment is 
the only one available. It should be mentioned that by and large this estimate did not include an estimate of value added in the so-called gray economy, although we can assume that the VAT system will tend to shrink that sector and thereby contribute to a growth of the tax base.

Item 2: Deliveries of goods and services abroad are exempted from the VAT because they will be consumed outside the country (the VAT is based on the destination principle). Therefore, the value of exports is subtracted from the initial figure in calculating the tax base.

Since a zero tax rate is implicitly applied to exports, this means that the tax paid in previous phases of the production chain is deducted; that is, in the case of exports it is fully refunded to the exporter. This avoids 'cascade' taxation, so that the tax base should not be increased to take that effect into account. Figures of the State Bureau of Statistics were used for the value of visible exports in kunas, and figures of the National Bank of Croatia expressed in US dollars, which were converted to kunas at the average exchange rate of the National Bank of Croatia, were used for the value of exports of non-factor services.

Item 3: According to the destination principle, the VAT taxes consumption at the place where it occurs. Therefore the value of imported goods and non-factor services is added to the base of the VAT. The sources of the data are the same as in Item 2.

Item 4: In the consumption type of VAT gross investments are not taxed. Stated more precisely, they are taxed, but the procedure for deducting prior taxes ultimately exempts them from the tax. This does not apply, however, to sectors whose deliveries within the country are exempted from the VAT, so that investments in those sectors of the economy, investments of households in housing, and investments of the state (which as a production sector is not a taxpayer) are included in the tax base.

In our estimate, then, only gross investments of entrepreneurial sectors which are not exempted from the VAT are subtracted from the tax base. Accordingly, the portion of aggregated sectors which include both taxed and exempted sectors which pertains to the taxed sectors and is deducted from the tax base was also estimated in this process. Thus, $30 \%$ of the value of investments made in the sector of financial and other services and in the sector of education and culture was deducted from the base. The figures of the State Bureau of Statistics on actual investments of legal entities on the principle of main business activity were used. 
Item 5: The sum of the value added of sectors exempted from the VAT is deducted from the tax base. Under the Croatian law the housing service and most social services are not taxed, and the sector of government administration and non-profit organizations is explicitly excluded as a taxpayer. Aside from that, most housing services of owner-occupied apartments and houses are implicit in nature.

In estimating this item, since official statistical data are lacking, we used estimates of the State Bureau for Macroeconomic Analyses and Forecasts on the value added in factor prices in these sectors: housing and municipal services, financial and other services, and the sector of social and government services and of services of non-profit organizations. In order to separate out the portion of services of those heterogeneous sectors which are not exempt from the VAT, we had to make an adjustment of the total value added. Thus in the case of housing and municipal services we deducted from the total value added that portion which pertains to municipal services. In the case of financial and other services we subtracted the portion which pertains to other business services $(50 \%)$, and in the case of public and other services we deducted the portion which pertains to entrepreneurial activity (8\%). All the adjustments were made on the basis of ratios of certain subsectors determined in 1992, for which there are detailed statistical data on the social product.

Finally, since the value added is given in the prices of factors, the necessary adjustment of the base for the VAT to account for the sales tax which might have been collected in those sectors was done as part of the adjustment at the aggregate level for the entire economy in Item 10.

Item 6: When there are exempted sectors in the VAT system, and when the credit method is used to compute the tax, then the phenomenon of what is called 'cascade' taxation occurs, since the value of their sales to taxable sectors cannot be deducted from the tax base. The sum of these deliveries, then, must be added to the tax base for the VAT. In our case, however, most deliveries of the exempted sectors fall in the category of final consumption, and this adaptation is not necessary. Financial services to the entrepreneurial sector are a partial exception. That is why we estimated the value of those services $(85 \%$ of bank revenues from commissions and service charges) on the basis of data of the Payments Bureau on the business operation of banks and other financial organizations. 
Item 7: In order to reduce the administrative costs of tax collection from a large number of small entrepreneurs, the Croatian VAT system has defined an income level below which the VAT is not paid (HRK 50,000 a year). So, just as with the exemptions mentioned previously in Item 5, their income must be deducted from the tax base. At the same time, their purchases from taxed sectors must be added to the tax base.

It is estimated that most individual farms and some small craftsmen and personal services will be exempted from the VAT thanks to this threshold. However, since we do not have figures on deliveries and purchases (input-output table) of those sectors, we used the equivalent procedure used in Item 5 for the exempted sectors. That is, it is valid to say that final deliveries of an exempted sector, minus purchases of intermediate goods from taxed sectors, are equal to the added value of the exempted sector minus the intermediate deliveries to the taxed sectors. On that basis we estimated the share of the total value added of the portion of the agricultural sector exempted from the tax by the income threshold and subtracted it from the tax base for the VAT. Since these are also sectors whose output is mainly destined for final consumption, either in kind or on the market, we did not have to add to the tax base their deliveries of intermediate goods to taxed sectors.

In the computation data were used from the State Bureau for Macroeconomic Analyses and Forecasts on the value added of aggregate sectors of agriculture and of the crafts and trades and personal services, and then an estimate of the share of small farmers (30\%), craftsmen and other entrepreneurs $(25 \%)$ in the total value added of the sectors on the basis of indirect indicators (their number and average income).

Items 8 and 9: Given the destination principle governing payment of the tax and the consumption type of the VAT, we need to add to the tax base expenditures of non-residents for consumption within the country and subtract expenditures for consumption of residents abroad. Here we used figures from the balance of payments on the spending of foreign tourists in the country and of Croatian tourists abroad. The present methodology of the balance of payments, because it records foreign exchange transactions, covers those two types of expenditures comparatively well.

We might mention here that we could have made this adjustment already in Items 2 and 3, but we felt that this approach provides greater transparency and has importance for the subsequent 
analysis.

Item 10: Up to this point calculation of the base for the VAT has included indirect taxes. So, in order to obtain the base for computation of the VAT we need to subtract that portion of revenues from indirect taxes being replaced by the VAT. In our case this is the revenue from the sales tax on goods and services. We should mention here that income from customs duties and other import charges and from special taxes (excise taxes) are included in the tax base for calculation of the VAT.

At this point we used figures of the Ministry of Finance on sales tax collection. Using the procedure described, we arrived at the base for computation of the VAT indicated under Item 12 in Table 5, from which the potential amount of the VAT was obtained by applying the rate of $22 \%$. Item 11 leaves open the possibility of adjusting the base either downward, which is usually the case when the VAT is introduced because of problems in achieving smooth operation in applying the system in all its phases, or upward, because of possible effects reducing evasion. We assumed that because of the relatively widespread sophistication of Croatian entrepreneurs in calculating the sales tax, the loss in the introductory phase will not be great. What is more, there is also the positive impact of reduction of the evasion which we have already mentioned. On this account our correction was at the level of $10 \%$ of the estimated base before that adjustment. This item is certainly arbitrary and a reflection of the conservative approach we have been pursuing in this work. It also covers errors and omissions in estimating all the items in the procedure for calculating the base.

We should emphasize here the importance of good preparation for introduction of the VAT system to reduce possible losses when it is introduced, which could go as high as $25-35 \%$ of the tax base (Bogetić \& Hassan, 1993).

At the end of the description of the estimation procedure we can conclude that consistent with the type of VAT, the tax base in Croatia consists basically of final consumption of the goods and services of residents (households and the state) and of non-residents in the country realized through the market, and outlays for investments and deliveries of intermediate goods of exempted sectors to sectors which are taxed.

\section{Analysis of the Results}


Below we will comment on the results of the estimate of the base and of revenues from the VAT over the period of 1994-1997 as shown in Tables 5 and 6.

We should note first of all that a significant change occurs between 1994 and 1995. The tax base and potential revenue from the VAT increased considerably. The revenue gap between the VAT and the sales tax dropped from the level of $4.2 \%$ to $0.8 \%$ of GDP. Two main factors were working to this end. First, there was a significant change in the structure of final consumption. The high relative growth of personal consumption and government expenditure, which is manifested in the large growth of the deficit in the balance of goods and services, considerably augmented the base for the VAT. Second, the change in the tax system carried out in mid-1994 with the introduction of excise taxes, whose full impact occurred in 1995, and the reduction in the number of rate brackets and rates of the sales tax helped to increase the tax base for the VAT. The impact of the 1994 tax reform is evident in Table 6. Both changes had the result that potential revenues from the VAT were brought closer to actual revenues from the sales tax in 1995.

That relationship will not undergo any essential change in the years to come. Minor changes are a consequence of the assumed scenario for movement of the various macroeconomic aggregates in that period, which is evident from the growth rates indicated in the tables.

A sizable growth of spending by tourists as compared to the 'lost' year of 1995 contributes to determination of this relative growth of the base and thereby of revenues from the VAT in 1996. At the same time, revenues from the sales tax are dropping because the rates were lowered. In 1997 the assumed relative slowdown of domestic final consumption is expected to reduce somewhat the base by comparison to the previous year.

It should be mentioned that in principle the rate of exchange affects the base and revenues from the VAT through its influence on the trend of exports and imports, but also through computation of the kuna value of the base used to compute the tax. For example, appreciation potentially will increase the trade deficit and will indirectly increase the base and revenues of the VAT, but at the same time it will reduce the base expressed in kunas.

Likewise, changes in tariff protection and in excise taxes, which will follow in the period after joining the World Trade Organization, will also have an influence on the base and revenues of the 
VAT. The total impact of those changes, which consist of direct and indirect effects, can be estimated with greater precision only by a model of the economy that would cover simultaneous influences of variables. 


\section{Table 5. Estimate of the Base and Revenues of the Value Added Tax}

\begin{tabular}{|c|c|c|c|c|c|c|c|}
\hline & \multicolumn{4}{|c|}{ Year (current prices, millions HRK) } & \multicolumn{3}{|c|}{ Growth Rate (\%) } \\
\hline & 1994 & 1995 & 1996 & 1997 & 95/94 & $96 / 95$ & 97/96 \\
\hline 1. GDP (market prices) & 85,229 & 94,564 & 102,572 & 111,258 & 11.0 & 8.5 & 8.5 \\
\hline 2. Minus exports & 39,290 & 38,072 & 43,465 & 48,382 & -3.1 & 14.2 & 11.3 \\
\hline 3. Plus imports & 40,672 & 49,985 & 55,577 & 59,881 & 22.9 & 11.2 & 7.7 \\
\hline 4. Minus investments of entrepreneurs in taxed sectors & 8,342 & 9,662 & 10,627 & 12,898 & 15.8 & 10.0 & 21.4 \\
\hline 5. Minus value added in exempted sectors (factor prices) & & & & & & & \\
\hline Housing rent & 4,812 & 5,201 & 5,617 & 6,066 & 8.1 & 8.0 & 8.0 \\
\hline Financial services & 3,821 & 3,422 & 3,764 & 4,141 & 4.3 & 10.0 & 10.0 \\
\hline Public services and non-profit organizations & 12,963 & 16,067 & 16,870 & 17,714 & 23.9 & 5.0 & 5.0 \\
\hline 6. Plus sales of intermediate products by exempted sectors to taxed sectors & 600 & 624 & 686 & 755 & 4.0 & 9.9 & 10.1 \\
\hline 7. Minus value added of entrepreneurs below the tax threshold & & & & & & & \\
\hline Private farmers & 2,429 & 2,514 & 2,715 & 2,932 & 3.5 & 8.0 & 8.0 \\
\hline Small craftsmen and tradesmen and services & 557 & 720 & 792 & 871 & 29.3 & 10.0 & 10.0 \\
\hline 8. Plus spending of foreigners in the country & 8,533 & 8,107 & 10,052 & 11,861 & -5.0 & 24.0 & 18.0 \\
\hline 9. Minus spending of residents abroad & 3,301 & 4,086 & 4,699 & 5,263 & 23.8 & 15.0 & 12.0 \\
\hline 10. Minus indirect taxes replaced by the VAT & 13,107 & 12,802 & 13,590 & 14,837 & -2.3 & 6.2 & 9.2 \\
\hline 11. Minus the collection gap (mistakes in estimation, start-up difficulties, etc.) & 4,226 & 6,073 & 6,675 & 7,065 & 43.7 & 9.9 & 5.8 \\
\hline 12. Base for computation of the VAT & 42,726 & 54,661 & 60,073 & 63,586 & 27.9 & 9.9 & 5.8 \\
\hline 13. Revenues from the VAT & 9,400 & 12,025 & 13,216 & 13,989 & 27.9 & 9.9 & 5.8 \\
\hline 14. VAT's share in GDP, in $\%$ & 11.03 & 12.72 & 12.88 & 12.57 & & & \\
\hline 15. Sales tax's share in GDP, in $\%$ & 15.38 & 13.54 & 13.25 & 13.34 & & & \\
\hline
\end{tabular}

Source: Explained in the text 


\section{Table 6. Structure of the Base}

\begin{tabular}{|l|r|r|r|r|r|r|r|}
\hline & \multicolumn{3}{|c|}{ Year (current prices, millions HRK) } & \multicolumn{4}{|c|}{ Growth Rate (\%) } \\
\hline & \multicolumn{1}{|c|}{1994} & \multicolumn{1}{|c|}{1995} & 1996 & 1997 & $95 / 94$ & $96 / 95$ & $97 / 96$ \\
\hline 1. Base, exclusively indirect taxes & 55,833 & 67,463 & 73,663 & 78,423 & 20.8 & 9.2 & 6.5 \\
\hline 2. Sales tax & 13,107 & 12,802 & 13,590 & 14,837 & -2.3 & 6.2 & 9.2 \\
\hline 3. Excise taxes & 1,814 & 4,944 & 5,339 & 5,767 & 172.5 & 8.0 & 8.0 \\
\hline 4. Customs duties, etc. & 3,487 & 3,939 & 4,406 & 4,707 & 13.0 & 11.9 & 6.8 \\
\hline 5. Pure base (1-2-3-4) & 37,425 & 45,778 & 50,328 & 53,112 & 22.3 & 9.9 & 5.5 \\
\hline 6. Base of the value added tax (1-2) & 42,726 & 54,661 & 60,073 & 63,586 & 27.9 & 9.9 & 5.8 \\
\hline
\end{tabular}

Source: Explained in the text

\section{REFERENCES:}

Bogetić, Z - Hassan, F. (1993), Determinants of value added tax revenue. World Bank Working Paper, WPS 1203

Cnossen, S. (1991), Design of the value added tax: lessons from experience. In: Khalilzadeh -

Shirazi, Shah, (1991)

Gillis, M. - Shoup, C. - Sicat, G.P, (eds) (1990), Value added taxation in developing countries.

Washington: World Bank

Kay, Y.A.- Davis, E.H. (1987), The VAT and services. Washington: World Bank

Khalilzadeh-Shirazi, J. - Shah, A. (1991), (eds) Tax policy in developing countries: A World Bank

Symposium. Washington: World Bank

Mackenzie, J. (1991), Estimating the base of the VAT in developing countries. The problems of

Exemptions. Washington: IMF Working Paper, WP 21

Shome, P.ed. (1995), Tax policy handbook. Washington: IMF

Tait, A. (1988), VAT: International practice and problems. Washington: IMF

Zee, H.H. (1995), Value added tax. In: Shome, P. ed. (1995) 